\title{
MENINGKATKAN PENGUASAAN LAGU DENGAN METODE EAR TRAINING PADA PEMBELAJARAN KELAS VOKAL
}

Petrus haning tridhora utomo

Guru ekstrakulikuler kelas vokal SD Mondial Semarang, Candi golf boulevard no 2, Indonesia

\section{S. Suharto}

Prodi Pendidikan Sendratasik, Fakultas Bahasa dan Seni, Universitas Negeri Semarang, Indonesia

\section{Info Artikel}

SejarahArtikel:

Diterima Juni 2016

Disetujui Juni 2016

Dipublikasikan Juni 2016

\section{Kata Kunci}

Ekstrakulikuler vokal, penguasaan lagu, kemampuan musikalitas, kemampuan ketrampilan

\begin{abstract}
Abstrak
Tujuan dari penelitian ini adalah untuk mengetahui apakah metode dapat meningkatkan penguasaan lagu di pembelajaran ekstrakurikuler kelas vokal SD Mondial Semarang. Hasil penelitian menunjukkan bahwa pembelajaran menggunakan metode ear training pada siswa yang mengikuti ekstrakurikuler vokal di SD Mondial Semarang bisa meningkatkan kemampuan vokal dan musik. Berdasarkan indikator ini, maka kemampuan menguasai lagu siswa ekstrakurikuler yang mengikuti vokal Semarang Mondial dapat ditingkatkan dengan metode pembelajaran ear training. Kondisi siswa sebelumnya ketika tahap pra sikulus yang memiliki kemampuan vokal yang baik hanya 5 siswa meningkat lagi di siklus 2 menjadi 21 siswa.
\end{abstract}

\begin{abstract}
The purpose of this research is to find out whether the method of ear training can increase the mastery track on extracurricular learning vocal classes in elementary Mondial Semarang. The research results showed that the learning method using ear training on students who follow in the primary extracurricular Mondial Semarang could increase the ability of vocal and musical ability. Based on these indicators, then the ability of mastering songs students extracurricular which follow the Semarang Mondial vocals can be increased with a learning method of ear training. Condition before treatment students who have good vocal abilities only 5 students increased after treatment in cycle 2 to 21 students.
\end{abstract}

$\bowtie$ Guru ekstrakulikuler kelas vokal SD Mondial ISSN 2301-6744 Semarang, Candi golf boulevard no 2, Indonesia Email: $\underline{\text { Haning06@gmail.com }}$ 


\section{PENDAHULUAN}

Pembelajaran pendidikan seni di sekolah umum dapat dipilahkan antara mata pelajaran seni yang resmi (sesuai dengan kurikulum) dalam arti dilaksanakan di dalam kelas atau disebut intrakurikuler, dan mata pelajaran seni (tidak harus sesuai kurikulum) yang dilaksanakan di luar kelas tetapi tetap di dalam sekolah atau disebut kegiatan ekstrakurikuler. Di antara keduanya memang ada sedikit perbedaan, terutama menyangkut capaian materi seni yang harus dikuasai siswa, yang pertama lebih terfokus kepada pencapaian pengalaman berkesenian (justifikasi kontekstual), sedangkan yang kedua selain pencapaian pengalaman berkesenian juga penguasaan keterampilan atau keahlian menurut cabang atau bidang seni yang sedang diminati (justifikasi tekstual) (Jazuli,2008: 21). Ekstrakurikuler adalah kegiatan yang dilakukan oleh para siswa sekolah, di luar jam belajar kurikulum standar. Kegiatankegiatan ini ada pada setiap jenjang pendidikan dari sekolah dasar sampai perguruan tinggi. Kegiatan ekstrakurikuler ditujukan agar siswa dapat mengembangkan kepribadian, bakat, dan kemampuannya di berbagai bidang di luar bidang akademik. Kegiatan ini di adakan secara swadaya dari pihak sekolah maupun siswa-siswi itu sendiri untuk merintis kegiatan di luar jam pelajaran sekolah. Kegiatan dari ekstrakurikuler ini sendiri dapat berbentuk kegiatan pada seni, olah raga, pengembangan kepribadian, dan kegiatan lain yang bertujuan positif untuk kemajuan dari siswa-siswi itu sendiri. Pengembangan kegiatan ekstrakurikuler merupakan bagian dari pengembangan institusi sekolah. Kegiatan ektrakurikuler sendiri bertujuan untuk mengembangkan bakat, kepribadian, prestasi dan kreativitas siswa dalam rangka mengembangkan pendidikan siswa seutuhnya. Secara khusus kegiatan ektrakurikuler bertujuan untuk Menyediakan lingkungan yang memungkinkan siswa didik untuk mengembangkan potensi bakat dan kemampuannya secara optimal. Memandu (artinya mengidentifikasi dan membina) dan memupuk (artinya mengembangkan dan meningkatkan) potensi-potensi siswa secara utuh. Pengembangan aspek afektif (nilai moral dan sosial) dan psikomotor (ketrampilan) untuk menyeimbangkan aspek kognitif siswa. Membantu siswa dalam pengembangan minatnya, juga membantu siswa agar mempunyai semangat baru untuk lebih giat belajar serta menanamkan rasa tanggung jawabnya sebagai seorang manusia yang mandiri (karena dilakukan diluar jam pelajaran). Ekstrakulikuler vokal di SD Mondial Semarang memang masih di hitung baru di bandingkan sekolah-sekolah lainya yang sudah lama ada ekstrakulikuler vokal tetapi SD Mondial sudah mulai eksis di Kota Semarang dimulainya dari SD Mondial yang sudah dipercaya oleh Kecamatan Candi Sari dari berbagai lomba yang diberikan tanggung jawab untuk mewakili Kecamatan Candi Sari untuk tingkat kota maupun nasional, dan kelompok vokal SD Mondial mulai eksis dan mempunyai tanggung jawab yang besar untuk selalu siap jika ada lomba-lomba yang berhubungan dengan pemerintahan. Oleh karena itu SD Mondial selalu mempersiapkan dari jauh hari dengan selalu rutin berlatih. Antusias siswa-siswi SD Mondial pun sangat bagus sekali, terbukti bertambah banyaknya anggota ekstrakulikuler vokal SD Mondial. Seiring bertambahnya peminat ekstrakulikuler vokal proses pembelajaranpun harus selalu diperbaiki dan dievaluasi terus menerus.

Bentuk metode atau penerapan pembelajaran untuk teknik vokal ternyata harus disediakan dan disiapkan yang sesuai dan relevan dengan tujuan pembelajarannya, disamping bentuk 
metode yang kiranya dapat menunjang pembelajaran teknik vokal pada siswa, adalah penerapan metode ear training yang berisi tentang gambaran bagaimana cara meningkatkan penguasaan lagu dalam pembelajaran ekstra vokal.

Maka dengan ini saya penulis sekaligus guru ekstrakulikuler vokal di SD Mondial tersebut akan menerapkan metode ear training ini untuk meningkatkan pembelajaran ekstrakulikuler vokal di SD tersebut. Salah satu harapannya agar siswa dapat semakin meningkat dalam menguasai suatu materi yang diajarkan dan semakin baik dalam mempraktekannya.

Tujuan penelitian ini adalah untuk mengetahui apakah metode ear training dapat meningkatkan penguasaan lagu pada pembelajaran ekstrakurikuler kelas vokal di SD Mondial Semarang.

Ear Training adalah latihan kemampuan mendengar, menurut Kodiyat (1983: 68), Ear training adalah latihan pendengaran secara sistematis, latihan vokal tanpa perkataan dan hanya dengan suku kata terbuka. Latihan pendengaran tersebut dilakukan dengan cara menselaraskan dengan not-not yang dihadapi. Dengan terbiasanya siswa mendengar secara bertahap, maka bayangan nada/not dari suatu lagu yang didengar akan dapat dibayangkan besar kecilnya dan tepat tidaknya lompatan nada.

Manusia normal sejak lahir sudah dibebani dengan kemampuan reaksi terhadap bunyi atau musik, sehingga tanpa kegiatan mendengar manusia tidak dapat memberikan reaksi terhadap rangsangan yang membentuk bunyi (Jamalus,1981: 49) Latihan pendengaran musik biasanya dilakukan dalam bentuk dikte yang berupa nada yang dinyanyikan kemudian ditirukan, yang sebelumnya didahului dengan latihan pendengaran dan latihan daya ingat. Dikte tersebut berupa melodi, kord, dan ritme. Latihan pendengaran ini membutuhkan konsentrasi yang sungguh- sungguh agar kesan musik dapat di mengerti dan bila dilakukan secara berulang- ulang dapat dijadikan dasar menuju tahap pelajaran membaca notasi. Florentinus (1997: 62) membagi lebih lanjut kemampuan mendengar not (Ear training) ke dalam tiga indikator kemampuan yang pertama yaitu; kemampuan mendengar dan mengingat ritme/irama, yang kedua kemampuan mendengar dan mengingat melodi/rangkaian nada, yang ketiga kemampuan mendengar dan mengingat kord/keselarasan gabungan nada. Menurut Benward yang dikutip oleh Sumaryanto (2001: 35), kemampuan pendengaran merupakan gabungan dari faktor kebiasaan dan pembawaan. Faktor kebiasaan dapat dikembangkan melalui latihan teratur, sedangkan faktor pembawaan murni berasal dari kemampuan diri yang berupa bakat musikalitas. Dalam proses mempelajari sebuah lagu perlu ditanamkan pengertian tentang rasa irama/ritme, agar siswa dapat menyanyikan sebuah lagu dengan dalam irama yang sesuai. Selain itu perlu ditanamkan juga pengertian tentang bayangan /memori nada, interval, dan melodi sehingga tidak mengalami kesulitan dalam menyanyikan sebuah lagu dengan benar. Dari penjelasan di atas dapat ditegaskan bahwa kemampuan mendengar not (Ear training) adalah tingkat kepekaan siswa dalam mendengarkan, mengingat, menuliskan dan menyuarakan kembali unsur-unsur musikal dalam bentuk notasi musik secara langsung, baik pada melodi, ritme maupun kord.

\section{METODE}

Metode penelitian yang digunakan adalah penelitian tindakan kelas dengan 2 siklus. Subjek penelitian ini adalah siswa ekstrakulikuler Vokal SD Mondial Kota Semarang. Siswa tersebut berjumlah 43 anak yang terdiri dari kelas 1 sampai 2 yang terdiri dari 18 anak dan kelas 3 sampai 5 yang terdiri 
dari 25 anak. Fokus penelitian ini adalah peningkatan dalam penguasaan lagu pada materi pembelajaran ekstrakulikuler vocal. Teknik pengumpulan data yang digunakan adalah teknik test praktik. Teknik analisis data yang digunakan adalah deskriptif persentase.

\section{HASIL PENELITIAN}

Mengenai kondisi awal pembelajaran ekstrakurikuler vokal di SD Mondial Semarang menunjukan beberapa gambaran bahwa pembelajaran aktrskurikuler vokal ini dengan kegiatan bernyanyi bersama tanpa menggunakan metode terntentu. Kondisi awal ini diperoleh dengan melakukan test awal pada siswa yang mengikuti ekstrakurikuler vokal di SD Mondial Semarang. Berdasarkan hasil penilaian pra siklus, kemampuan penguasaan lagu dalam aspek musikalitas siswa yang mengikuti ekstrakurikuler diperoleh data sebagai berikut:

Tabel 1 Kemampuan Musikalitas Siswa pada Kegiatan Siswa

\begin{tabular}{|llll|}
\hline Skor & Kriteria & Frekuensi & Persentase (\%) \\
\hline 20 & Sangat Kurang & 3 & 6,98 \\
40 & Kurang & 17 & 39,53 \\
60 & Cukup & 18 & 41,86 \\
80 & Baik & 5 & 11,63 \\
100 & Sangat Baik & 0 & 0 \\
Jumlah & & 43 & 100 \\
\hline
\end{tabular}

Sumber: Olah data hasil penelitian 2016

Berdasarkan hasil penilaian pada Tabel 1 dan Gambar 1 di atas menunjukan bahwa siswa yang memiliki kemampuan musikalitas sangat kurang ada 6,98\%, siswa yang memiliki kemampuan musikalitas kurang ada 39,53\%, siswa yang memiliki kemampuan musikalitas cukup ada $41,86 \%$, siswa yang memiliki kemampuan musikalitas baik ada $11,63 \%$, dan belum ada siswa yang memiliki kemampuan musikalitas dengan sangta baik.

Selain dengan kemampuan musikalitas dalam bernyanyi juga di butuhkan tes vokal. Tes ini untuk mengetahui apakah peserta ekstrakulikuler vokal bisa dan hafal dengan baik dan bisa menyanyi dengan baik atau belum,sehingga perlu diberikan tindak lanjut. Berdasarkan hasil penilaian pada pra siklus,keterampilan vokal siswa yang mengikuti ekstrakurikuler di SD Mondial Kota Semarang diperoleh data sebagai berikut:

Tabel 2 Kondisi Kemampuan Ketrampilan Vokal Pada Pra Siklus

\begin{tabular}{llll}
\hline Skor & Kriteria & frekuensi & Persentase (\%) \\
\hline 20 & Sangat Kurang & 1 & 2,33 \\
40 & Kurang & 22 & 51,16 \\
60 & Cukup & 16 & 37,21 \\
80 & Baik & 4 & 9,30 \\
100 & Sangat Baik & 0 & 0 \\
Jumlah & & 43 & 100 \\
\hline
\end{tabular}

Berdasarkan Tabel 2 dan Gambar 2 di atas menunjukan bahwa kemampuan siswa dalam hal vokal pada pra siklus ada $2,33 \%$ kemampuan sangat kurang, ada 51,16\% yang memiliki kemampuan vokal kurang, ada
$37,21 \%$ yang memiliki kemampuan vokal cukup, ada 9,3\% yang memiliki kemampuan vokal baik

Faktor yang menghambat pembelajaran ekstrakurikuler vokal di SD Modial Kota 
Semarang adalah metode pembelajaran yang digunakan masih kurang menarik dan kurang mengeksplor peserta didik. Hal itu menjadikan kemampuan penguasaan khususnya kemampuan musikalitas dan kemampuan vokal masih rendah.

\section{Pelaksaan Tindakan}

\subsection{Hasil dan Pembahasan Siklus 1}

Sebelum mendapatkan hasil penelitian baik secara kualitatif maupun kuantitaif terlabih dahulu dilakukan pembelajaran menggunakan metode ear training. Adapun langkah-langkah pembelajaran dengan metode ear training adalah sebagai berikut: Pertama, dalam proses mengamati peserta didik mendengar materi lagu yang akan dipelajari dengan rasa ingin tahu dan konsentrasi. Dalam tahap ini, yang digunakan adalah mendengar dalam metode ear training. Kedua adalah proses menanya. Dalam proses ini, peserta didik tanya jawab mengenai judul lagu, pencipta lagu, nada yang di dengar dengan sikap saling menghargai pendapat teman dan menggunakan bahasa yang santun. Peserta didik dan guru juga bertanya jawab mengenai seputar lagu yang sudah didengar. Tanya jawab tersebut dilakukan dengan bahasa yang santun dan sikap kritis. Dalam tahap ini yang digunakan adalah mengingat dalam metode ear training. Ketiga adalah proses menalar. Proses ini diintegrasikan dengan tahap menuliskan dalam metode ear training. Secara individu peserta didik menyusun beberapa pertanyaan mengenai lagu yang sudah di dengar dengan sikap percaya diri. Langkah ini akan menuntun peserta didik pada tahap mempraktekkan agar lebih baik. Keempat merupakan proses utama yaitu mencoba. Proses ini juga diintegrasikan dengan tahap terpenting dalam metode ear

training yaitu menyuarakan. Dalam tahap ini, peserta didik secara bersama - sama mencoba menyanyikan lagu yang sudah di dengar dengan bersamaan di putarnya lagu tersebut. Peserta didik juga diarahkan pada sikap semangat dan percaya diri. Kemudian peserta didik dalam tahap ini juga akan menemukan kesulitan nada yang sudah mereka dengar dan akan kita bahas dan betulkan kembali. Dengan demikian peserta didik lebih mudah dan termotivasi dalam menyanyikan kembali lagu tersebut. Proses terakhir dalam kegiatan inti adalah mengomunikasikan/ membuat jejaring. Dalam proses ini, peserta didik akan di bentuk kelompok dan akan menyanyikan lagu tersebut secara berkelompok dengan rasa percaya diri. Peserta didik lain kemudian mendengarkan temannya dengan sikap saling menghargai dan tanggung jawab.

Selama proses pembelajaran dengan metode ear training dilakukan pengamatan kegiatan siswa untuk mengetahui kesulitan siswa dan mengetahui kekurangan pembalajaran yang dilakukan. Sesudah peserta ekstrakurikuler vokal mendapatkan pembelajaran menggunakan metode ear training, dilakukan tes keterampilan musikalitas dan tes vokal pada semua peserta ekstrakurikuler untuk mengetahui perkembangan penguasaan lagu. Berikut ini hasil tes kemampuan musikalitas siswa pada siklus

Tabel 3 Kemampuan Musikalitas Siswa pada Siklus 1

\begin{tabular}{llll}
\hline Skor & Kriteria & frekuensi & Persentase (\%) \\
\hline 20 & Sangat Kurang & 0 & 0 \\
40 & Kurang & 2 & 4,65 \\
60 & Cukup & 16 & 37,21 \\
80 & Baik & 19 & 44,19 \\
100 & Sangat Baik & 6 & 13,95 \\
Jumlah & & 43 & 100 \\
\hline
\end{tabular}

Sumber: Olah data hasil penelitian 2016 
Berdasarkan hasil penilaian pada Tabel 3 dan Gambar 3 di atas menunjukan bahwa kemampuan musikalitas siswa yang masih kurang adalah $4,65 \%$, siswa yang memiliki kemampuan cukup ada $37,21 \%$, siswa yang memiliki kemampuan baik ada 44,19\%, dan siswa yang memiliki kemampuan musikalitas sangat baik ada $13,95 \%$.
Penilaian tes yang dilakukan pada aspek kedua yaitu aspek vokal. Berdasarkan hasil penilaian diperoleh data kemampuan vokal siswa pada siklus 1 sebagai berikut:

Tabel 4 Kemampuan Ketrampilan Vokal Siswa pada Siklus 1

\begin{tabular}{llll}
\hline Skor & Kriteria & frekuensi & Persentase (\%) \\
\hline 20 & Sangat Kurang & 0 & 0 \\
40 & Kurang & 1 & 2,33 \\
60 & Cukup & 12 & 27,91 \\
80 & Baik & 22 & 51,16 \\
100 & Sangat Baik & 8 & 18,60 \\
Jumlah & & 43 & 100 \\
\hline
\end{tabular}

Sumber: Olah data hasil penelitian 2016

Berdasarkan hasil penilaian pada Tabel 4 di atas menunjukan bahwa siswa ayng memiliki kemampuan ketrampilan vokal kurang ada $2,33 \%$, siswa yang memiliki kemampuan cukup ada $27,91 \%$, siswa yang memiliki kemampuan vokal baik ada51,16\%, siswa yang memiliki kemampuan vokal sangat baik ada $18,6 \%$.

Hasil pengamatan pembelajaran menggunakan metode ear training pada siklus 1 digunakan untuk refleksi agar pembelajaran siklus 2 menjadi lebih baik. Pembelajaran pada siklus 1 siswa masih canggung,karena seperti tidak terbiasa dengan metode yang digunakan. Metode ear training selanjutnya di jelaskan kembali kepada siswa tentang cara-cara pembelajaran menggunakan metode ear training sehingga siswa mampu mengikuti pembelajaran lebih baik dari pada siklus 1 .

santun. Peserta didik dan guru juga bertanya jawab mengenai seputar lagu yang sudah didengar. Tanya jawab tersebut dilakukan dengan bahasa yang santun dan sikap kritis. Dalam tahap ini yang digunakan adalah mengingat dalam metode ear training. Ketiga adalah proses menalar. Proses ini diintegrasikan dengan tahap menuliskan dalam metode ear training. Secara individu peserta didik menyusun beberapa pertanyaan mengenai lagu yang sudah di dengar dengan

\subsection{Hasil dan Pembahasan Siklus 2}

Kegiatan siklus 1 dijadikan sebagai pengalaman, sehingga pada siklus 2 pembelajaran relatif lebih mudah diikuti siswa ekstrakurikuler di SD Mondial Kota Semarang. Langkah-langkah pembelajaarn menggunakan metode ear training pada siklus 2 adalah sebagai berikut; pertama guru menjelaskan tentang cara metode ear training yang akan digunakan, kedua dalam proses mengamati peserta didik mendengar materi lagu yang akan dipelajari dengan rasa ingin tahu dan konsentrasi. Dalam tahap ini, tahap ini yang digunakan adalah mendengar dalam metode ear training. Kedua adalah proses menanya. Dalam proses ini, peserta didik tanya jawab mengenai judul lagu, pencipta lagu, nada yang di dengar dengan sikap saling menghargai pendapat teman dan menggunakan bahasa yang

sikap percaya diri. Langkah ini akan menuntun peserta didik pada tahap mempraktekkan agar lebih baik. Keempat merupakan proses utama yaitu mencoba. Proses ini juga diintegrasikan dengan tahap terpenting dalam metode ear training yaitu menyuarakan. Dalam tahap ini, peserta didik secara bersama - sama mencoba menyanyikan lagu yang sudah di dengar dengan bersamaan di putarnya lagu tersebut. Peserta didik juga diarahkan pada sikap semangat dan percaya diri. Kemudian peserta 
didik dalam tahap ini juga akan menemukan kesulitan nada yang sudah mereka dengar dan akan kita bahas dan betulkan kembali. Dengan demikian peserta didik lebih mudah dan termotivasi dalam menyanyikan kembali lagu tersebut. Proses terakhir dalam kegiatan inti adalah mengomunikasikan/ membuat jejaring. Dalam proses ini, peserta didik akan di bentuk kelompok dan akan menyanyikan lagu tersebut secara berkelompok dengan rasa percaya diri. Peserta didik lain kemudian mendengarkan temannya dengan sikap saling menghargai dan tanggung jawab.

Hasil kemampuan penguasaan lagu khsusunya pada aspek musikalitas dan vokal pada kegiatan ini ada 41 siswa yang mendapat nilai lebih dari 70. Secara rinci kemampuan musikalitas siswa disajikan ke dalam Tabel 4.5 berikut ini:

Tabel 5 Kemampuan Musikalitas Siswa pada Siklus 2

\begin{tabular}{llll}
\hline Skor & Kriteria & Frekuensi & Persentase (\%) \\
\hline 20 & Sangat Kurang & 0 & 0 \\
40 & Kurang & 0 & 0 \\
60 & Cukup & 2 & 4,65 \\
80 & Baik & 21 & 48,84 \\
100 & Sangat Baik & 20 & 46,51 \\
Jumlah & & 43 & 100 \\
\hline
\end{tabular}

Sumber: Olah data hasil penelitian 2016

Berdasarkan hasil penilaian pada siklus 2 yang disajikan pada Tabel 5 di atas menunjukan bahwa siswa yang memiliki kemampuan musikalitas cukup ada 4,65\%, siswa yang memiliki kemampuan musikalitas baik ada
$48,84 \%$, dan siswa yang memiliki musikalitas sangat baik ada $46,51 \%$.

Hasil penguasaan kemampuan vokal diperoleh data pada siklus 2 sebagai berikut ini:

Tabel 6 Kemampuan Ketrampilan Vokal Siswa pada Siklus 2

\begin{tabular}{llll}
\hline Skor & Kriteria & frekuensi & Persentase (\%) \\
\hline 20 & Sangat Kurang & 0 & 0 \\
40 & Kurang & 0 & 0 \\
60 & Cukup & 1 & 2,33 \\
80 & Baik & 26 & 60,47 \\
100 & Sangat Baik & 16 & 37,21 \\
\hline
\end{tabular}

Sumber: Olah data Hasil Penelitian 2016

Berdasarkan hasil penilaian pada siklus 2 yang disajikan dalam Tabel 4.6 dan Gambar 6 di atas menunjukan bahwa siswa yang memiliki kemampuan ketrampilan vokal cukup ada $2,33 \%$, siswa yang memiliki kemampuan vokal baik ada 60,475 dan siswa ayng memiliki kemampuan vokal sangat baik ada $37,21 \%$.

Pada bab sebelumnya telah diuraikan bahwa permasalahan dalam penelitian ini adalah kemampuan penguasaan lagu siswa yang mengikuti ekstrakurikuler di SD Mondial Kota
Semarang masih kurang baik. Oleh karena itu perlu menggunakan metode yang tepat untuk memecahkan masalah atau memberikan solusi dari masalah tersebut. Metode yang digunakan dalam pembelajaran untuk memberikan solusi adalah dengan metode ear training.

Berdasarkan hasil penelitian menunjukan bahwa pembelajaran menggunakan metode ear training dapat meningkatkan kemampuan penguasaan lagu khususnya pada kemampuan musikalitas dan kemampuan vokal siswa 
dalam menyanyikan sebuah lagu. Hal itu menjadikan ekstrkurikuler vokal yang ada di SD Mondial Kota Semarang menjadi lebih baik dalam bernyanyi. Tes penilaian yang dilakukan untuk mengukur penguasaan lagu dalam siswa yang mengikuti ekstrakurikuler adalah tes kemampuan musikal dan tes kemampuan vokal siswa. Berikut ini Peningkatan kemampuan musikalitas dari pra siklus sampai dengan siklus 2 disajikan dalam tabel 7 berikut ini:

Tabel 7 Peningkatan Kemampuan Musikalitas Siswa

\begin{tabular}{lllllll}
\hline Siklus & Pra siklus & \multicolumn{3}{c}{ Siklus 1} & Siklus 2 \\
\hline Kriteria & F & $\%$ & F & $\%$ & F & $\%$ \\
Samgat kurang & 3 & 2,33 & 0 & 0 & 0 & 0 \\
Kurang & 17 & 51,16 & 2 & 4,65 & 0 & 0 \\
Cukup & 18 & 37,21 & 16 & 37,21 & 2 & 4,65 \\
Baik & 5 & 9,30 & 19 & 44,19 & 21 & 48,84 \\
Sangat baik & 0 & 0 & 6 & 13,95 & 20 & 46,51 \\
\hline
\end{tabular}

Sumber: Olah data hasil penelitian 2016

Penerapan metode eart training untuk pembelajaran ekstrakurikuler siswa di SD Mondial Kota Semarang dapat meningkatkan kemampuan musikalitas siswa. hasil penilaian dari pra siklus sampai dengan siklus 2 menunjukan bahwa jumlah siswa yang memiliki kemampuan musikalitas baik maupun sangat baik selalu mengalami peningkatan. Pada pra siklus belum ada siswa yang memiliki kemampuan musikalitas sangat baik, pada siklus 1 ada siswa yang sudah memiliki kemampuan musikalitas sangat baik $13,95 \%$ dan meningkat lagi pada siklus 2 menjadi $46,51 \%$.

Penilaian tes kemampuan ketrampilan vokal siswa dari pra siklus sampai dengan siklus 2 diperoleh data peningkatan sebagai berikut ini:

Tabel 8 Peningkatan Kemampuan Ketrampilan Vokal Siswa

\begin{tabular}{lllllll}
\hline Siklus & Pra siklus & \multicolumn{3}{c}{ Siklus 1} & Siklus 2 \\
\hline Kriteria & F & $\%$ & F & $\%$ & F & $\%$ \\
Samgat kurang & 3 & 2,33 & 0 & 0 & 0 & 0 \\
Kurang & 17 & 51,16 & 2 & 2,33 & 0 & 0 \\
Cukup & 18 & 37,21 & 16 & 27,91 & 2 & 2,33 \\
Baik & 5 & 9,30 & 19 & 51,16 & 21 & 60,47 \\
Sangat baik & 0 & 0 & 6 & 18,60 & 20 & 37,21 \\
\hline
\end{tabular}

Sumber: Olah data hasil penelitian 2016 
Berdasarkan hasil penelitian tindakan kelas di atas, maka terbukti bahwa pembelajaran menggunakan metode ear training dapat meningkatkan penguasaan lagu siswa ekstrakurikuler di SD Mondial Kota Semarang. Ear training adalah latihan pendengaran secara sistematis, latihan vokal tanpa perkataan dan hanya dengan suku kata terbuka (Kodiyat, 1983:68). Latihan pendengaran tersebut dilakukan dengan cara menselaraskan dengan not-not yang dihadapi. Dengan terbiasanya siswa mendengar secara bertahap, maka bayangan nada/not dari suatu lagu yang didengar akan dapat dibayangkan besar kecilnya dan tepat tidaknya lompatan nada. Berdasarkan pendapat Kodiyat tersebut maka dengan latihan vokal dan kemampuan musikalitas akan dapat meningkatkan kemampuan penguasaan lagu.

Manusia normal sejak lahir sudah dibebani dengan kemampuan reaksi terhadap bunyi atau musik, sehingga tanpa kegiatan mendengar manusia tidak dapat memberikan reaksi terhadap rangsangan yang membentuk bunyi ( Jamalus, 1981: 49) Latihan pendengaran musik biasanya dilakukan dalam bentuk dikte yang berupa nada yang dinyanyikan kemudian ditirukan, yang sebelumnya didahului dengan latihan pendengaran dan latihan daya ingat. Pembelajaran dengan metode ear training yaitu siswa mendengarkan teman pada saat menyanyi kemudian dirinya menirukan, maka akan mempermudah peningkatan kemampuan vokal dan kemampuan musikalitasnya sehingga siswa dapat meningkatkan penguasaan lagu. Dengan demikian hipotesis yang menyatakan bahwa pembelajaran menggunakan metode ear training dapat meningkatkan kemampuan penguasaan lagu diterima.

\section{DAFTAR PUSTAKA}

Arikunto, S. 1998. Prosedur Penelitian Suatu Pendekatan Praktek. PT. Rineka. Cipta. Jakarta.

Basrowi\& Suwandi. (2008). Memahami Penelitian Kualitatif. Jakarta: Rineka Cipta. Cangara.

Darsono, M. 2000. Belajar dan Pembelajaran. Semarang : IKIP.

Depdikbud. (1990). Kamus Besar Bahasa Indonesia. Jakarta: Balai Pustaka.

Depdikbud. (1994). Petunjuk Pelaksanaan Kegiatan Ekstrakurikuler. Jakarta: Departemen Pendidikan dan Kebudayaan.
Dimyati, M., 1999, Belajar dan Pembelajaran, Rieka Cipta, Jakarta

Destiannisa, A. (2013). IMPLEMENTASI METODE PENDEKATAN KOGNITIF DALAM PEMBELAJARAN PADUAN SUARA. Harmonia: Journal Of Arts Research And Education, 12(2). doi:http://dx.doi.org/10.15294/harmonia.v12i2.25 24

(1994). Belajar dan Pembelajaran. Jakarta: proyek. Pembinaan dan Peningkatan Mutu Tenaga Dikti.

Harsono. (2007). Teori dan Metodologi Pelatihan. Sekolah Pascasarjana Universitas Pendidikan Indinesia, Bandung

Hatch, E dan Farhady, H, 1981, Research Design and Statistics for Applied Linguistics, Teheran: Rahnama Publications.

Jamalus. 1981.Musik Untuk SPG.Jakarta: Depdikbud

Jazuli, M,Hum. (2008). Paradigma Kontekstual Pendidikan Seni, Penerbit Unesa University Press, Semarang.

Kountur, Ronny. 2003. Metode Penelitian Untuk Penulisan Skripsi \& Tesis (Cetakan Ke-1) Jakarta: PPM

Kodyat, H 1983. Sejarah Pariwisata dan Perkembangnannya di Indonesia. PT Gramedia. Pustaka Utama. Jakarta.

Lutan, Rusli. (1986). Pengelolaan Interaksi Belajar Mengajar Intrakurikuler, Kokurikuler, dan Ekstrakurikuler.Jakarta; Departemen Pendidikan dan Kebudayaan Universitas Terbuka

Moleong, L. (2000). Metodologi Penelitian Kualitatif. Bandung: Rosda karya.

Nazir, Muhammad. 1988, Metode Penelitian, Ghalia Indonesia, Jakarta.

Moh. Uzer dan Lilis. (1993). Upaya Optimalisasi Kegiatan Belajar Mengajar. PT. Remaja Rosdakarya: Bandung.

Prasojo Udi.1989. Implemen Kurikulum 1994 Kertangkes. Skripsi. Semarang UNNES. 
Purwanto, 1991, Administrasi dan Supervisi Pendidikan, Bandung: Remaja Rosdakarya.

Soemanto, Wasty dan Hendyat Soetopo, 1982, Dasar Teori Pendidikan Dunia: Tantangan Bagi Para Pemimpin Pendidikan, Surabaya: Usaha Nasional

Sugandi, Achmad, dkk. 2004. Teori Pembelajaran. Semarang: UPT MKK. UNNES.

Syaiful B., Djamarah. 2000. Prestasi Belajar Dan Kompetensi Guru. Surabaya : Usaha Nasional.

Sugiyono ,1998, Metode Penelitian Administrasi, Alfabeta, Bandung.

Suharto, S. (2013). PROBLEMATIKA PELAKSANAAN PENDIDIKAN SENI MUSIK DI SEKOLAH KEJURUAN NON SENI. Harmonia: Journal Of Arts Research And Education, 12(1). doi:http://dx.doi.org/10.15294/harmonia.v12i1.22 21

Suharto, S. (2011). PENGEMBANGAN MATERI DAN KEGIATAN PEMBELAJARANNYA DALAM KURIKULUM TINGKAT SATUAN PENDIDIKAN BIDANG SENI MUSIK. Harmonia: Journal Of Arts Research And Education, $\quad 8(3)$. doi:http://dx.doi.org/10.15294/harmonia.v8i3.780

Kristyana, L., \& Suharto, S. (2014). Singing as a Strategy to Enhance the Ability to Speak for Early Childhood. Harmonia: Journal Of Arts Research And Education, 14(2), 123-130. doi:http://dx.doi.org/10.15294/harmonia.v14i2.32 93

(2010). MetodePenelitian Kuantitatif Kualitatif \& RND. Bandung: Alfabeta.

Tim MKDK IKIP Semarang,1996.Belajar dan Pembelajaran, Depdikbud, IKIP Semarang.

Winarno, Florentinus, Gregorius.1997.Kimia Pangan dan Gizi. Jakarta:Gramedia Pustaka Utama.

Yudha M.1998. Pengembangan Kegiatan KoEkstrakurikuler. Jakarta: Depdikbud. 